\title{
TYPES OF POLITENESS IN ENGLISH: LINGUISTIC ASPECTS AND PEDAGOGICAL IMPLICATIONS
}

\author{
Olha Ivashchyshyn
}

\author{
Ivan Franko National University of Lviv, \\ 1, Universytetska Str., Lviv, Ukraine, 79000 \\ ivasho@gmail.com
}

Nataliya Kashchyshyn

\author{
Ivan Franko National University of Lviv, \\ 1, Universytetska Str., Lviv, Ukraine, 79000 \\ natakashchyshyn@gmail.com
}

\begin{abstract}
The paper focuses on the research of lexical and grammatical means of politeness as one of the universals in language usage, which expresses the concern of the speaker for interlocutors in particular social contexts. It considers four types of politeness as a linguistic phenomenon: showing the value and respect, softening the communication, assisting in creating the effect of a compliment, and deliberating elimination of the importance of a request. In addition, the use of modal verbs and modal expressions are discussed. Furthermore, the paper outlines the concept of linguistic politeness and discusses its interaction with sociocultural variables. Finally, it describes the TALAS (Teaching and Learning Academic Subjects) web-application implemented in virtual English classrooms, which is equipped with tools for working with well-organized interactive assignments and contributes to acquiring knowledge on the linguistic means of expressing politeness.

Key words: politeness, linguistic unit, grammatical form, sociocultural variable, virtual environment, web-application.

Introduction. The paper focuses on the research of politeness as one of the universals in language usage expressing concern and consideration for interlocutors in particular social contexts. Politeness is quite often understood as a tool for maintaining friendly relations, enabling communication even between potentially aggressive people and minimizing confrontation.

Language means of expressing politeness have continuously been in the focus of linguists and educators, who have been trying to search for universal ideas in order to contribute to developing communication at various levels and in many areas. The amount of investigations has greatly increased due to the contemporary processes of integration and globalization. With the development of new approaches to education, teaching politeness means have also become an important component in language classes.

The aim of our research is to substantiate linguistic objectivity of politeness strategies by analyzing lexical and grammatical means of is expressing politeness. Furthermore,
\end{abstract}

(C) Ivashchyshyn O., Kashchyshyn N., 2020 
we have set the task to outline the concept of politeness and to discuss the interaction of linguistic politeness with sociocultural variables. Finally, we offer suggestions for using the TALAS (Teaching and Learning Academic Subjects) web-application to teach lexical and grammatical forms of expressing politeness through interactive assignments in the virtual English classroom situation.

Politeness can be analyzed through various linguistic and nonlinguistic means, as it is connected not only with language but also with the manners and behavior of people, and varies across cultures. Our research is based on the analysis of linguistic means of expressing politeness in English written and oral discourses.

Previous Research in the Area. The study of communicative situations is one of the most important areas of research. Politeness as the focus of effective communication has been studied by many linguists in the course of the communication theory development. The investigations in the politeness means and strategies, which help to achieve positive results of communication between interlocutors, have considerably increased their scope in the past few years. Our research is based on the approaches supported by such linguists as M. Cremona, S. Assimakopoulos, A. Vella, N. Ambady, J. Koo, F. Lee, R. Rosenthal, R. Lakoff, R. Scollon, S. Scollon, G. Eelen, etc., who study politeness in terms of various aspects and strategies.

Most researchers agree that the processes of verbalization of politeness help in understanding the communicants and play a leading role in achieving successful results of communication. Therefore, verbalization of politeness directly belongs to the dominant components of communicative acts.

Such authors as M. Cremona, S. Assimakopoulos, and A. Vella emphasize that politeness tends to be equivalent to manners and behavior for the majority of people; however, its conception varies across cultures, and what is considered polite in one culture may be perceived as rude in another. As such, politeness can be realized through different means, one of the most common of these being the use of language [3, p. 767].

R. Scollon and S. Scollon discuss politeness based on the essential topics in crosscultural communication and focus, in particular, on the discourse of men and women, professional discourse, intergenerational discourse, etc. The researchers highlight the role of politeness as sophisticated language means and focus on various approaches to this language phenomenon in different countries of our culturally diverse world [11, p. 115].

N. Ambady, J. Koo, F. Lee, and R. Rosenthal have pointed to a variety of politeness means and variables in degrees of politeness [1, p. 998]. P. Brown and S. Levinson define politeness as a language and body tools for keeping good relations between the speaker and listeners or readers [2, p. 12]. Apart from this, politeness is understood by R. Lakoff as the ability of people to use interactive strategies depending on communicative situation that allow a communicator to make a good impression on the interlocutor and create a positive self-image or, on the contrary, expand his/her personal space [9, p. 295].

J. Pfister, M. Yaqubi, K. Saeed, and M. Khaksari analyze the maxim of politeness as well as the direct and indirect polite offers and invitations. They point out that offers and invitations give rise to implicatures, and polite speech acts should be performed with 
maximum efficiency in order to avoid the addressee to think that the invitation is insincere or not genuine [10, p. 1267; 13, p. 55].

We share the ideas mentioned above and agree with G. Eelen that means of linguistic politeness should be analyzed with the regard for a detailed study of vocabulary and grammar $[4$, p. 35].

Among many challenging questions of ongoing research, a basic question remains open due to the universal character of the concept of politeness: what are specific linguistic features of politeness which contribute to the formation of unique strategies supporting mutual understanding between people in many areas? In this research, we attempt to answer this question proceeding from the study of the language means of expressing politeness.

Methods. The research is based on the linguistic analysis of 600 patterns of sentences and interactive utterances from English written and oral communicative situations containing language units expressing politeness. We have studied politeness as a linguistic phenomenon taking into consideration the discourse topic, focus of conversation and degree of verbal expression in the frame of such social contexts as the type of interlocutor (friend, family member, relative, colleague, classmate, random communicant), social relations (work, education, service), place of communication (country, region, city, village), gender (male, female), and cultural group (nation, generation). Accordingly, the methods of cognitive and semantic analysis have been applied to study specific features of the language environment in these social contexts.

The size of the selected language corpus and the aim of the research determined the decision to use certain methodological strategies. For the purpose of outlining the concept of linguistic politeness based on the analysis of lexical and grammatical means and of defining the interaction of linguistic politeness with sociocultural variables, we analyzed and systematized the selected language material in accordance with the semantic groups typical of various social and cultural contexts. In order to suggest the opportunities for the implementation of theoretical results, we applied a pragmatic approach to elaborating interactive tests based on the TALAS web-application to practice the usage of the language units under research.

It is also worth emphasizing that the analysis of politeness means is challenging in terms of both methods and approaches. On the one hand, we employ linguistic analysis, which introduces theoretical and pragmatic approaches focusing on the usage of politeness in various social contexts. On the other, these approaches help in differentiating between four types of politeness considered below. Both methods and approaches provide the grounds for substantiating linguistic objectivity of politeness strategies and analyzing their sociocultural variables.

Results and Discussion. The analysis of written and oral patterns containing language units which express politeness in various social contexts has resulted in the differentiation between four types of this linguistic phenomenon: politeness, showing value and respect towards the listener or reader; politeness. softening communication to avoid being excessively direct or forceful; politeness, assisting in creating the effect of a hidden or indirect compliment; politeness, deliberating elimination of the importance of a request, which is crucial for the speaker. 
There are many ways in which we can show that we value and respect our listeners or readers. In more formal situations, we use such polite phrases as:

Dear ladies and gentlemen, please welcome our guests!

Thank you for kind words!

Excuse me, I would like to ask you something.

May I take this book, madam?

In addition, in formal contexts when we do not know people and want to show respect, we use such titles as $M r$. + family name, $M s$. + family name, sir, madam, doctor (Dr), professor (Prof.), etc.

In less formal situations, when we speak and write, we usually try not to be excessively direct. There are a number of ways in which we can do this with the help of the words which can be classified as "softening words". We can use the following words to make softer what we say:

It's kind of hot in here, isn 't it?

Could you just turn the radio down a little, please?

Your reciting a poem could possibly be improved.

You may need to spend more time learning English.

It is also possible to use the vocabulary, which linguists call "vague language" in the form of words or phrases and which is very common in speaking, to make times and numbers sound less direct, for instance: about, sort of, and that kind of thing.

Quite often we may find lexical means which assist in creating the effect of a hidden or indirect compliment:

I really like the way you approach this matter.

I really appreciate the way you have done this.

It is always important for me to do the best job I can, and I know the same is true for you.

This vocabulary is capable of producing politeness and at the same time helps to achieve the communicative goals of the speaker. It is quite typical of conducting negotiations in order to deal with conflict situations.

We can also observe some cases of the very sophisticated politeness expressing intended pessimism and deliberate elimination of the importance of a request which is crucial for the speaker:

I am sure you will not be very much in favor of doing this.

I believe you cannot help them in this case.

It is a very small thing we would appreciate from your friends.

You can hardly make the decision to help us.

These examples show that the speaker's language possesses the efficient potential for achieving numerous and versatile communicative goals.

Among the grammar means which help to express politeness, we can find certain modal verbs, especially the past forms of the modal verbs can, may, shall and will (could, might, 
should, and would), to be more polite or less direct. We can also use other modal expressions (certainly, possibility, be likely to, be supposed to be). We often do this when we ask for something or ask someone to do something:

Would you help me, please, sir? (more polite/less direct than Will you follow me?)

Would you mind not smoking, please?

Could you show me the way to the Opera House?

I'll certainly go with you. Well, he is supposed to be a good doctor.

Is there a possibility that you come without delay this time?

Most people associate politeness with such expressions as "honorific forms", "polite behavior", "kindness", "consideration", "personal relationship" and "a way of speaking". This demonstrates that speakers are aware of the important role of politeness in maintaining good human relations through verbal communication. According to L. Tao, who studied the concept of politeness, different cultural and linguistic groups express politeness in different ways [12, p. 158]. However, we believe that politeness is used in terms of universal principles and can involve showing generally accepted values and standards. We also share the ideas of T. Konrad, who emphasizes that politeness is used in both universal and specific terms, finally taking into account social realities [8, p. 162].

Politeness can also be analyzed with regard for the sociocultural variables which speakers employ in choosing the degree of politeness. According to J. Holmes, the speaker's use of "softening words" alleviates the face dimension of his/her request or offer to a large extent [6, p. 41]. In addition, by using the honorifics, such as Mr., Mrs., Miss, Sir, Dr., etc., the speaker maintains a social distance with the person who possesses more relative power.

Sharing the idea of B. Fraser, who claims that every society has a set of social norms attributing a certain behavior and way of thinking [5, p. 221], we believe that politeness is a universal means which is widespread in all sociocommunicative spheres; at the same time, it displays significant variability in certain situations, allowing the speakers to achieve their goals.

Based on the study of sociocultural variables, we distinguish positive politeness, for instance, the demonstration of interest and sympathy, and negative politeness expressing pessimism, apologizing, etc. Also, we support the ideas of J. Holmes who insists that in the estimation of face-threatening acts, three basic sociocultural variables should be taken into consideration: the social distance between interlocutors, the degree of power on each other, and ranking [6, p. 102]. Moreover, according to the researcher's examination of the distribution and functions of a range of specific verbal politeness means in women's and men's speech, there are certain social reasons for gender differences [6, p. 52].

Our analysis shows that these differences can be observed in interactional strategies, compliments, and apologies, particularly in the areas of education and professional careers. In general, it is important to emphasize that politeness can be viewed both as the basis for maximally efficient communication and the deviation from it, and that politeness is the means of developing various social relations in society.

Our concern is that a profound understanding of politeness as a linguistic phenomenon, of its strategies, and lexical and grammatical forms ensures success in mastering English 
communication. In the contemporary situation caused by the pandemic spreading of Covid-19 throughout the world, it is important to apply innovative methods for teaching academic subjects, English in particular, to students in virtual classrooms based on the use of information technologies. There are many Internet resources that help to develop and practice students' language skills, providing them with the tools for acquiring theoretical knowledge and completing online lexical and grammatical assignments. Such online platforms as Microsoft Teams, Zoom, Google Meet, Cisco Webex, etc. allow teachers to deliver online courses, develop communication skills of their students in real life-time situations, do interactive grammar tests, and watch presentations and videos. Other benefits of online learning allow students to link web-applications and to become independent in learning. One of them is the TALAS web-application [7] which we have implemented into our English classes.

TALAS is equipped with tools for working with well-organized interactive exercises which intensify the students' perception and cognition and contributes to acquiring knowledge on the linguistic means of expressing politeness. This web-application as a multifunctional environment challenges the adancement of students' language skills, makes this process manageable, and brings innovative perspectives on teaching English. TALAS is based on the work of two types of users: a teacher and a student. It provides the teacher with the tools for creating interactive practical assignments to develop students' skills. This web-application is for both students' group and individual activities and supports the monitoring of progress results with the help of the evaluation system. Furthermore, TALAS enables the students to view their mistakes and to read teacher's explanations. It creates a new learning space in which the users are autonomous. In addition to interactive assignments, this web-oriented application supports developing writing skills and embeds YouTube videos and audio resources. Thus, the means of politeness are learnt and practiced by students in various ways based on authentic materials. The obtained students' feedback has confirmed that implementation of TALAS facilitates self-learning process, promotes knowledge acquisition, makes learning faster, more enjoyable, self-directed, effective and transferable to new situations.

Conclusions. This paper has discussed the concept of politeness drawing attention to the importance of acquiring both theoretical and practical knowledge of lexical and grammatical means of politeness. Based on the analysis of lexical means in various social contexts, we have substantiated linguistic objectivity of politeness strategies by analyzing four types of this linguistic phenomenon.

The research allows us to understand the importance of the sociocultural variables of politeness for developing effective communication in society and provides the grounds for distinguishing positive and negative types of politeness. It also shows that the concept of politeness in communication is specific to a particular sociocultural environment, being at the same time characterized by a generally recognized sense of values and standards. In this context, the concept of politeness is understood as a universal means used in all social spheres of communication, which allows the speakers to achieve their goals and contribute to the development of social relationships in society. 
Finally, the paper advocates the use of the TALAS web-application for teaching language means of politeness in order to meet the requirements of contemporary education with highly developed information technologies. TALAS creates a new learning space in which the users can acquire knowledge on lexical and grammatical means of politeness through interactive assignments and authentic video and audio resources. The paper discusses the results of its implementation in virtual English classrooms.

We believe that this research opens the space for a further study of linguistic means of politeness and nonlinguistic strategies of this phenomenon in terms of their influence on achieving positive results in communication. We would recommend future researchers to focus on the peculiarities of politeness means and strategies used in different areas of professional activity and conduct the comparative analysis of politeness in the frame of intercultural communication in various language environments.

\section{REFERENCES}

1. Ambady N., Koo J., Lee F., Rosenthal R. More than words: Linguistic and nonlinguistic politeness in two cultures. Journal of Personality and Social Psychology. 1996. № 70(5). P. 996-1011.

2. Brown, P. \& Levinson, S. Politeness: Some Language Universals in Language Usage. Cambridge : Cambridge University Press, 1987. 345 p.

3. Cremona M., Assimakopoulos S., Vella A. The Expression of Politeness in a Bilingual Setting: Exploring the Case of Maltese English. Russian Journal of Linguistics. 2017. Vol. 21. № 4. P. 767-788.

4. Eelen G. A Critique of Politeness Theories. Manchester : St. Jerome Publishing, 2001. $280 \mathrm{p}$.

5. Fraser B. Perspectives on politeness. Journal of Pragmatics. 1990. № 14 (2). P. 219-236.

6. Holmes J. Women, Men and Politeness. London \& New York : Routledge, 2013. 264 p.

7. Ivashchyshyn O., Dovbenko V. TALAS. 2017. URL: http://talas.dx.am/about.php

8. Konrad T. Traditional and Modern Views: The Social Constitution and the Power of Politeness. Politeness in language: studies in its history, theory and practice. 1992. P. $155-191$

9. Lakoff R. The Logic of Politeness: Or minding your p's and q's. Papers from the 9th Regional Meeting of the Chicago Linguistic Society. 1973. Vol. 9. P. 292-305.

10. Pfister J.Is there a need for a maxim of politeness? Journal of Pragmatics. 2010. № 42. P. $1266-1282$.

11. Scollon R., Scollon S. Intercultural communication: A discourse approach. Oxford : Blackwell, 1995. $271 \mathrm{p}$.

12. Tao L. The Concepts of "Politeness": A Comparative Study in Chinese and Japanese Verbal Communication. Intercultural Communication Studies XXII. 2013. Vol. 2. P. 151-165.

13. Yaqubi M., Saeed K., Khaksari M. Conversational Maxim View of Politeness: Focus on Politeness Implicatures Raised in Performing Persian Offers and Invitations. Theory and Practice in Language Studies. Vol. 6. No. 1. P. 52-58. 


\title{
ТИПИ ВВІЧЛИВОСТІ В АНГЛІЙСЬКІЙ МОВІ: ЛІНГВІСТИЧНІ ТА ПЕДАГОГІЧНІ АСПЕКТИ
}

\section{Ольга Іващишин}

\author{
Львівський начіональний університет імені Івана Франка, \\ вул. Університетська, 1, м. Львів, Украӥна, 79000 \\ ivasho@gmail.com
}

Наталія Кащишин

\begin{abstract}
Львівський національний університет імені Івана Франка, вул. Університетська, 1, м. Львів, Україна, 79000

natakashchyshyn@gmail.com
\end{abstract}

Статтю присвячено дослідженню лексичних та граматичних засобів ввічливості - одного 3 універсальних явищ у мові, яке виражає відношення мовця до співрозмовників у конкретному соціальному контексті. У статті розглянуто чотири типи ввічливості як мовного явища: демонстрація цінності та поваги, пом'якшення спілкування, допомога у створенні ефекту компліменту та навмисне усунення важливості прохання. Крім того, проаналізовано використання модальних дієслів та модальних виразів для вираження ввічливості.

Також у статті розглянуто концепт лінгвістичної ввічливості та проаналізовано ії взаємодію із соціокультурними особливостями комунікації. 3'ясовано, що ввічливість $\epsilon$ універсалією, яка поширюється у спілкуванні у всіх соціальних сферах, але вирізняється особливою специфікою в певних ситуаціях, зумовлених прагненням мовця досягти своїх цілей. На основі дослідження соціокультурних особливостей виділено позитивну ввічливість, наприклад, демонстрацію зацікавленості, співчуття, та негативну ввічливість, яка виражає песимізм, прохання вибачення тощо. Встановлено, що соціокультурні особливості вираження ввічливості спостерігаються в стратегіях взаємодії між співрозмовниками у різних сферах, зокрема й у сферах освіти та професійної діяльності. Зроблено висновок, що ввічливість слід розглядати як основу максимально ефективного спілкування і що вона є одним із засобів розвитку різноманітних соціальних відносин у суспільстві.

Стаття завершується описом веб-додатка TALAS (Teaching and Learning Academic Subjects), впровадженого у віртуальні заняття з англійської мови і створеного для роботи в Інтернеті на основі програмного забезпечення для виконання інтерактивних завдань, які дають можливість вивчати англійську мову та здобувати практичні навички використання лексичних та граматичних засобів вираження ввічливості. Описано структуру цього навчального середовища, види завдань, методи контролю й оцінки результатів засвоєння знань, а також здійснено диференціацію типів користувачів та розглянуто їхні функції.

Ключові слова: ввічливість, лінгвістична одиниця, граматична форма, соціокультурна особливість, віртуальне середовище, веб-додаток. 